\title{
RADIOCARBON RESERVOIR AGE VARIATIONS IN THE SOUTH PERUVIAN UPWELLING DURING THE HOLOCENE
}

\author{
Michel Fontugne ${ }^{1} \cdot$ Matthieu Carré $^{\bullet}$ Ilhem Bentaleb ${ }^{2} \cdot$ Michèle Julien $^{3} \cdot$ Danièle Lavallée $^{3}$ \\ ABSTRACT. In Quebrada de los Burros in coastal southern Peru (Tacna department), human settlements containing shells \\ and charcoal deposits have been excavated since 1995. The sea surface ${ }^{14} \mathrm{C}$ reservoir ages, estimated by calculating the dif- \\ ference of ${ }^{14} \mathrm{C}$ age between marine shells and terrestrial organic materials, exhibit high values during the lower and middle \\ Holocene and decrease abruptly after $4000 \mathrm{cal}$ BP. The increase of reservoir age at around 7000-8000 cal BP suggests an \\ enhancement of Peruvian coastal upwelling intensity and changes in ocean circulation at intermediate depth.
}

\section{INTRODUCTION}

Recent studies in paleo-oceanography and paleoclimate focused on the radiocarbon reservoir age $(R)$ of surface seawaters since they could provide indications on oceanic circulation both for surface and/or deep-intermediate waters (Siani et al. 2000, 2001; Reimer and McCormac 2002; Southon et al. 2002). The classical approach consists in measuring the ${ }^{14} \mathrm{C}$ age difference between a terrestrial organic vegetal sample and a contemporaneous marine shell. Such a conjunction of samples is not often encountered except in coastal archaeological sites.

Here, we present new results from the southern Peruvian coast which provide some information about the upwelling system variability and its relation with El Niño events.

\section{MATERIAL AND METHODS}

\section{Sample Location}

Samples were collected at Quebreda de los Burros $\left(18^{\circ} 1^{\prime} \mathrm{S} ; 70^{\circ} 50^{\prime} \mathrm{E}\right)$ and neighboring sites (Cañon site and Inca site) both located in the Tacna department in the northern Atacama Desert (Figure 1). Quebrada de los Burros is a narrow valley oriented roughly north/south. This valley is about $150 \mathrm{~m}$ above mean sea level and the archaeological site is located less than $1 \mathrm{~km}$ from the shore (see Lavallée et al. 1999a, b, for details; Fontugne et al. 1999). All the shells and organic matter samples come from a narrow area restricted to the gully and excavations (about $400 \mathrm{~m} \times 50 \mathrm{~m}$ ). At the mouth of Quebrada, on a marine terrace $10 \mathrm{~m}$ above present sea level, we collected also charcoal, wood, and shells in an Inca site. The Cañon site is located $500 \mathrm{~m}$ from the Quebrada de los Burros sites in a larger and parallel valley at the same elevation. Only in Quebrada, springs occur(red) that created wetlands in very restricted areas and water availability for prehistoric people (Fontugne et al. 1999).

\section{Sampling Procedures}

Reservoir ages are generally estimated by calculating the difference of ${ }^{14} \mathrm{C}$ age between marine shells and terrestrial organic materials supposed to be contemporaneous. However, many problems in estimation of marine reservoir ages have been due to problematical associations. In order to illus-

\footnotetext{
${ }^{1}$ Laboratoire des Sciences du Climat et de l'Environnement, UMR 1572-CEA/CNRS, Domaine du CNRS, F-91198-Gif sur Yvette cedex, France. Corresponding author. Email: Michel.Fontugne@1sce.cnrs-gif.fr.

${ }^{2}$ Institut des Sciences de l'Evolution de Montpellier, UMR 5554, Place Eugène Bataillon CC064 F-34095 Montpellier cedex 5, France.

${ }^{3}$ Archéologie des Amériques, CNRS, Maison de l'Archéologie et de l'Ethnogie, 21, Allée de l'Université, F-92023-Nanterre cedex, France.
}

(C) 2004 by the Arizona Board of Regents on behalf of the University of Arizona Proceedings of the 18th International Radiocarbon Conference, edited by N Beavan Athfield and R J Sparks RADIOCARBON, Vol 46, Nr 2, 2004, p 531-537 


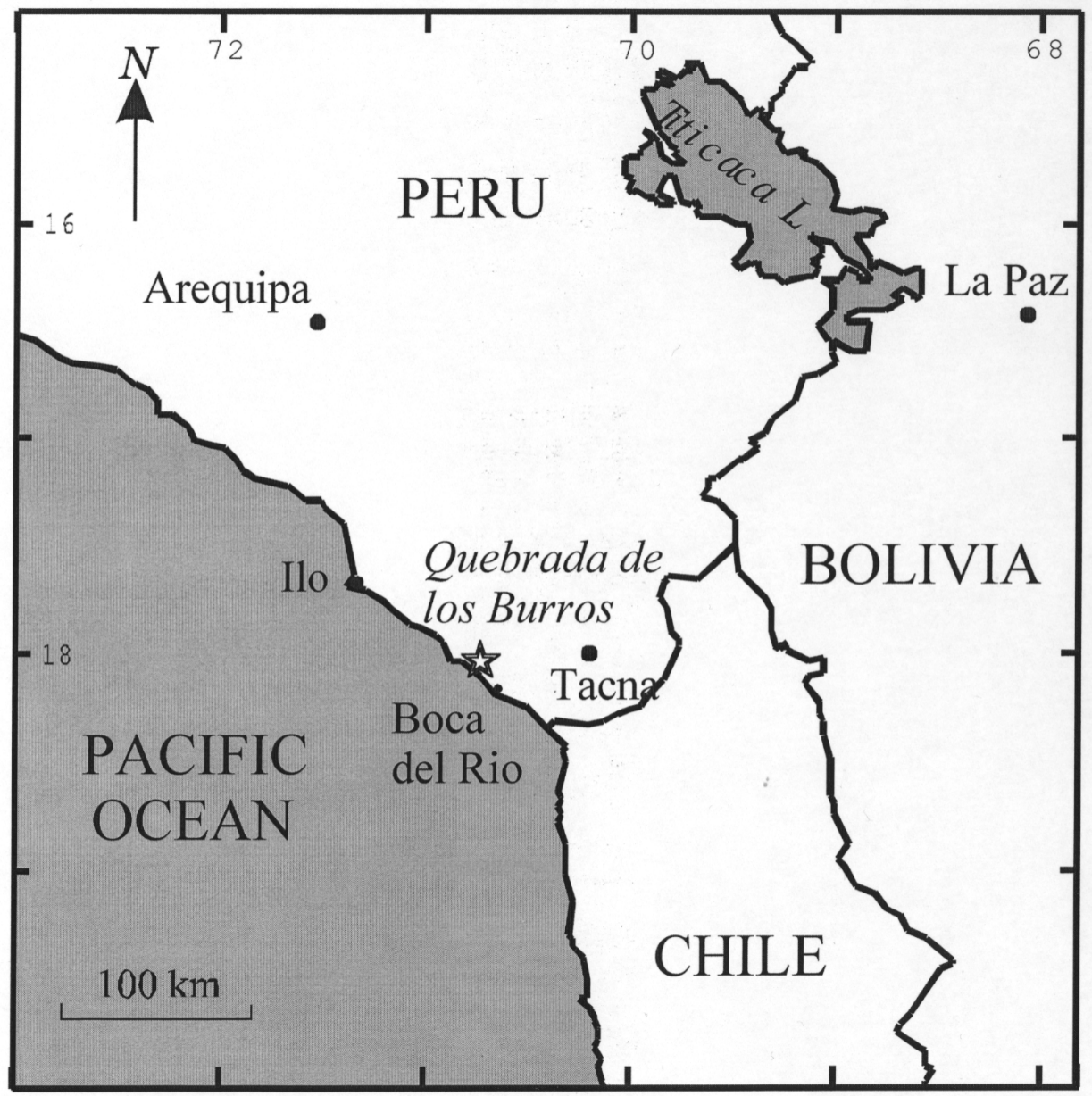

Figure 1 Location of the Quebrada de los Burros site

trate this difficulty, we used results of dating previously obtained at different locations of the archaeological site during different excavation campaigns. Associations were based on stratigraphical correlations or on archaeological interpretation attributing each settlement level to a cultural phase. Results reported in Table 1 led us to perform a specific sampling in order to avoid problems of the samples' location, and in interpretation of sedimentology and stratigraphy units in the site.

Paired samples of charcoals and marine shells (Concholepas concholepas, Mesodesma donacium) stratigraphically associated were selected in different archaeological levels. They were strictly in connection (charcoals were within the shell). We tried to select shells without any visible trace of alteration. Dating was performed on shell that contained micro-charcoals (less than $1 \mathrm{~mm}$ ) using both $\beta$-counting and accelerator mass spectrometry (AMS) techniques.

Others samples were collected within 3 cross-sections in a gully within the Quebrada. These crosssections have been already described by Fontugne et al. (1999) and Usselman et al. (1999). They contain mollusk shells eaten by man, associated with organic layers containing a mixture of plant detritus, with probably aquatic terrestrial plant remains and also charcoal powder, as revealed by pollen analyses. Here, too, samples were collected in connection. Results are in reported in Table 2. 
Table $1{ }^{14} \mathrm{C}$ conventional ages of marine shell and terrestrial organic samples, calibrated ages, and shell reservoir ages at Quebrada de los Burros, southern Peru. Samples were collected during different excavation campaigns and were not strictly in connection.

\begin{tabular}{lllllllll}
\hline $\begin{array}{l}\text { Laboratory } \\
\text { nr }\end{array}$ & $\begin{array}{l}\text { Sample } \\
\text { nr }\end{array}$ & Unit nr & Nature & $\begin{array}{l}\text { Conventional } \\
\text { age }\end{array}$ & $\begin{array}{l}\delta^{13} \mathrm{C} \\
(\%)\end{array}$ & $\begin{array}{l}\text { Calibrated } \\
\text { age }\end{array}$ & $\begin{array}{l}\text { Cal BP (yr) } \\
\text { range }\end{array}$ & $\begin{array}{l}\text { Reservoir } \\
\text { age }\end{array}$ \\
\hline Gif-10634 & 5087 & QLB 3 & Organic layer & $8040 \pm 105$ & -19.7 & 8996 & $9254-8592$ & $275 \pm 121$ \\
Gif-11453 & - & QLB23 & Shell & $8315 \pm 60$ & 0.0 & - & - & - \\
GifA 97289 & 5092 & A3 NIV 2B & Charcoal & $6630 \pm 70$ & -20.5 & 7548 & $7611-7336$ & $215 \pm 76$ \\
Gif-10689 & 5158 & N2B & Shell & $6845 \pm 30$ & -0.2 & - & - & - \\
Gif-10635 & 5066 & QLB4 & Organic layer & $7320 \pm 80$ & -14.9 & 8150 & $8326-7944$ & $-10 \pm 94$ \\
Gif-11450 & - & QLB 20 & Shell & $7310 \pm 50$ & -0.9 & - & - & - \\
Gif-10636 & 5067 & QLB5 & Organic layer & $6940 \pm 60$ & -16.3 & 7725 & $7921-7615$ & $155 \pm 78$ \\
Gif-11451 & - & QLB21 & Shell & $7095 \pm 50$ & 0.0 & - & - & - \\
GifA 97287 & 5056 & B3 NIV2A & Charcoal & $6460 \pm 60$ & -15.6 & 7416 & $7432-7252$ & $350 \pm 100$ \\
GifA 97288 & 5057 & C1 NIV 2A & Charcoal & $6510 \pm 60$ & -22.0 & 7424 & $7552-7270$ & $400 \pm 100$ \\
Gif-10399 & 5021 & N2a & Shell & $6110 \pm 80$ & -3.0 & - & - & - \\
\hline
\end{tabular}

Table $2{ }^{14} \mathrm{C}$ conventional ages of marine shell and terrestrial organic samples collected strictly in connection, calibrated ages, and shell reservoir ages at Quebrada de los Burros, southern Peru.

\begin{tabular}{|c|c|c|c|c|c|c|c|c|}
\hline $\begin{array}{l}\text { Laboratory } \\
\mathrm{nr}\end{array}$ & $\begin{array}{l}\text { Sample } \\
\mathrm{nr}\end{array}$ & Unit nr & Nature & $\begin{array}{l}\text { Conventional } \\
\text { age }\end{array}$ & $\begin{array}{l}\delta^{13} \mathrm{C} \\
(\% 0)\end{array}$ & $\begin{array}{l}\text { Calibrated } \\
\text { age }\end{array}$ & $\begin{array}{l}\text { Cal } \mathrm{BP}(\mathrm{yr}) \\
\text { range }\end{array}$ & $\begin{array}{l}\text { Reservoir } \\
\text { age }\end{array}$ \\
\hline Gif-10633 & 5086 & QLB2 & Organic layer & $8160 \pm 70$ & -15.0 & 9030 & 9399-8781 & $700 \pm 148$ \\
\hline Gif-10400 & 5035 & - & Shell & $8860 \pm 130$ & -1.0 & & & \\
\hline Gif-10634 & 5087 & QLB3 & Organic layer & $8040 \pm 105$ & -19.7 & 8996 & $9254-8592$ & $740 \pm 126$ \\
\hline Gif-10401 & $5031-2$ & - & Shell & $8780 \pm 70$ & 0.3 & & & \\
\hline Gif-10648 & 5088 & QLB17 & Organic layer & $3700 \pm 40$ & -15.0 & 4057 & $4146-3874$ & $745 \pm 57$ \\
\hline Gif-10404 & 5011 & - & Shell & $4445 \pm 40$ & 0.3 & & & \\
\hline GifA 99341 & 5323 & D9/2inf & Charcoal & $6090 \pm 80$ & -25.3 & 6894 & $7179-6690$ & $980 \pm 113$ \\
\hline GifA 99509 & 5323 & D9/2inf & Shell & $7070 \pm 80$ & 0.6 & & & \\
\hline GifA 99576 & 5292 & E9/2sup & Charcoal & $6560 \pm 90$ & -17.9 & 7430 & $7573-7272$ & $920 \pm 120$ \\
\hline GifA 99510 & 5295 & E9/2sup & Shell & $7480 \pm 80$ & 0.6 & & & \\
\hline Gif-10643 & 5080 & QLB12 & Organic layer & $7390 \pm 50$ & -15.3 & 8175 & $8330-8030$ & $735 \pm 58$ \\
\hline Gif-10646 & 5083 & QLB15 & Shell & $8125 \pm 30$ & 0.5 & & & \\
\hline Gif-10645 & 5082 & QLB14 & Organic layer & $6595 \pm 75$ & -13.6 & 7234 & $7415-7278$ & $565 \pm 110$ \\
\hline Gif-10647 & 5084 & QLB16 & Shell & $7160 \pm 80$ & 0.7 & & & \\
\hline Gif-10629 & 5074 & Cañon & Charcoal & $3120 \pm 80$ & -25.3 & 3341 & $3473-3065$ & $475 \pm 120$ \\
\hline Gif-10722 & 5074 & Cañon & Shell & $3595 \pm 90$ & 0.0 & & & \\
\hline GifA 100347 & 5406 & E5-6N4 & Charcoal & $6500 \pm 80$ & - & 7422 & $7558-7254$ & $1290 \pm 144$ \\
\hline GifA 100348 & 5406 & E5-6N4 & Shell & $7790 \pm 120$ & - & & & \\
\hline Gif-11457 & - & Site Inca/QLB31 & Wood & $375 \pm 30$ & -22.9 & 455 & $484-313$ & $675 \pm 42$ \\
\hline Gif-11456 & - & Site Inca/QLB 31C & Shell & $1050 \pm 30$ & -0.5 & & & \\
\hline GifA 100142 & 5373 & DE9/fond N2 & Charcoal & $6090 \pm 110$ & - & 6894 & $7231-6670$ & $550 \pm 121$ \\
\hline Gif-10649 & 5061 & $\mathrm{~N} 2 \mathrm{a}$ & Shell & $6640 \pm 50$ & -0.4 & & & \\
\hline Gif-10642 & 5079 & QLB11 & Organic layer & $8650 \pm 70$ & -13.4 & 9550 & 9888-9490 & $1075 \pm 114$ \\
\hline Gif-11452 & - & QLB22 & Shell & $9725 \pm 90$ & -0.1 & & & \\
\hline GifA 100343 & 5383 & B0C5/N4 5383 & Charcoal & $7360 \pm 100$ & -16.5 & 8167 & $8349-7963$ & $520 \pm 135$ \\
\hline GifA 100342 & 5383 & B0C5/N4 5383 & Shell & $7880 \pm 90$ & -0.4 & & & \\
\hline
\end{tabular}

\section{Hardwater or Old Wood Effects}

Hardwater effect and/or old wood effect are common problems in estimation of marine reservoir ages. In Quebrada, the hardwater effect could influence the aquatic plants, possibly contributing to these organic layers, and would result from dissolution of old carbonate and contamination by old bicarbonate or dissolved $\mathrm{CO}_{2}$ that could be used by the plant through photosynthesis processes. This effect is highly improbable in a hyper-arid region and, secondly, because the volcanic origin of the substratum (Formacion Chocolate) covered by sand sediment, is devoid of carbonate. 
Taking into account these observations and the coherence of these dates with those obtained for paired charcoal and shell in similar levels in the archaeological site, we admit that no aging due to hardwater effect occurs. Inversely, if we consider that such an aging would have occurred for these organic layers, it would imply a younger actual age and, consequently, a larger increase of sea surface reservoir age than we found. Such results would be hardly compatible with literature data or with other data obtained with charcoals and shells in Quebrada. Similarly, secondary alteration or recrystallization of shell carbonate would lead to the fixation of younger carbon and younger ages, meaning that our calculations of reservoir effect were underestimated.

The "old wood" problem results from the hyper-arid conditions in this region that promote longterm preservation of organic material which could be used by people. This effect gives low or negative $R$ values like those observed by Kennett et al. (2002) in the same region. It does not apparently occur at Quebrada de los Burros.

Whatever we consider, if hardwater or old wood effects or shell recrystallization have affected one or both paired samples, it would lead to an actual marine reservoir age that would be higher than we estimate. $R$ values reported in Table 2 have to be considered as minimal values.

\section{Analytical Procedures}

${ }^{14} \mathrm{C}$ dating was performed using beta-counting gas proportional counter and AMS facilities at Gif sur Yvette. Shells were cleaned using either dilute $\mathrm{HCl}$ ( $\beta$-counting samples) or sandblaster followed by acid treatment for AMS samples (Tisnérat et al. 2001) in order to remove the superficial part of the shell that might have been re-crystallized (Vita-Finzi and Roberts 1984). Charcoals and organic layers were prepared using classical treatments. Results are expressed as conventional ages (Stuiver and Pollack 1977) and calibrated age according to Stuiver et al. (1998).

\section{RESULTS AND DISCUSSION}

Results of the first study are reported in Table 1 . All $R$ values are smaller than the mean ocean reservoir age ( $400 \mathrm{yr}$ ) and are not compatible with an upwelling pattern that always prevailed in this region during the Holocene period. This illustrates that sampling needs to be performed very carefully; moreover, in order to study reservoir ages variations, a specific sampling would be recommended. Comparison of dates obtained by long distance correlation between different archaeological levels at different places in these sandy excavations is very confusing. The Quebrada de los Burros site presents a low sedimentation rate and archaeological levels that are not very thick. In this context, a possible penetration of shell in the underlying archaeological level is probable.

All the results of the second sampling are reported in Table 1 and Figure 2. The chronology is derived from ${ }^{14} \mathrm{C}$ conventional ages of terrestrial organic origin and extends from the Inca period $375 \pm 30{ }^{14} \mathrm{C}$ BP to $8650 \pm 70{ }^{14} \mathrm{C} \mathrm{BP}(455-9550 \mathrm{cal} \mathrm{BP})$. No human settlements or organic deposits could be found between 375 and $3200{ }^{14} \mathrm{C}$ BP. During the early- and mid-Holocene, differences between ${ }^{14} \mathrm{C}$ ages of shell and charcoal ( $R$ values) are high, ranging between 700 and $1230 \mathrm{yr}$. The "old wood" problem, giving low or negative $R$ values like those observed by Kennett et al. (2002) in the same region, do not apparently occur at Quebrada de los Burros. Nevertheless, lower $R$ values were observed around 6090 and 6595 and 7390 and $7360{ }^{14} \mathrm{C}$ BP. Between $3000{ }^{14} \mathrm{C}$ BP and the present, reservoir ages dropped down to low values (less than $700 \mathrm{yr}$ ), in good agreement with modern values $590 \pm 40 \mathrm{yr}$ and in agreement with Stuiver and Braziunas (1993) and Owen (2002). The large variations observed for reservoir age imply that for dating archaeological sites, the use of modern ${ }^{14} \mathrm{C}$ reservoir age correction (as it is done generally) could introduce uncertainties greater than $500 \mathrm{yr}$. 


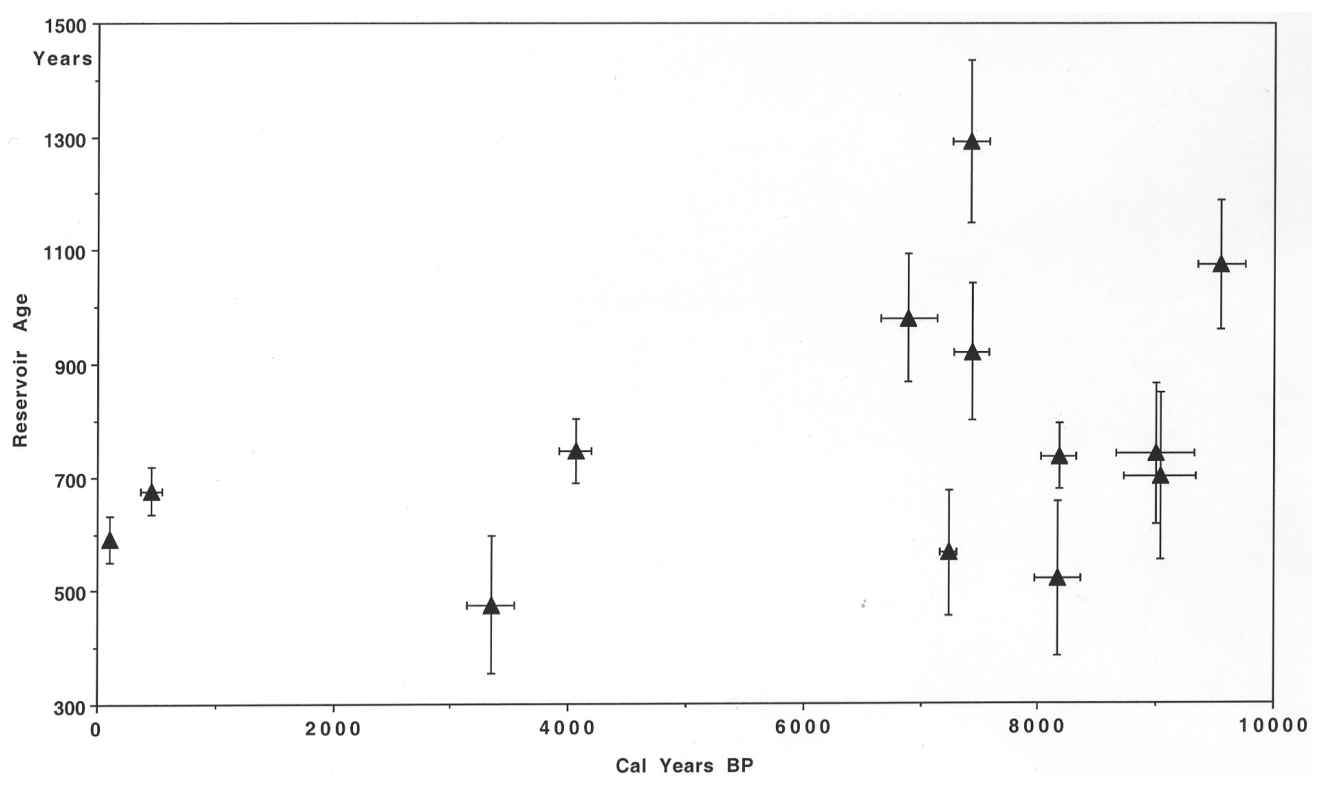

Figure 2 Variation of reservoir age of surface seawater versus time $\left({ }^{14} \mathrm{C}\right.$ cal BP). The errors quoted are $1 \sigma$.

The increase of reservoir age in upwelling areas is generally interpreted as an enhancement of upwelling intensity which brings deeper waters to the surface. Such an interpretation corroborates the hypothesis developed by Fontugne et al. (1999). They suggest that reinforced upwelling would generate more fogs condensing at mid-altitude $(600-1000 \mathrm{~m})$ in the Andes. This precipitation provides enough humidity to insure vegetation growth and food for guanaco hunted by fishergatherer/hunter people living on the coast (Lavallée et al. 1999a, b). The increased fog production was certainly the origin of water resources in Quebrada. Conversely, when reservoir ages are low and upwelling is weak, no human settlements are found. Paleo-oceanographic reconstructions in equatorial upwelling and the Peru-Chile current give arguments supporting these observations (see references). Data obtained in Quebrada suggest lower sea surface temperatures during the early midHolocene period and agree with this hypothesis. Fish consumed by man at that period belong to a fauna colder than that observed today (Lavallée et al. 1999b), and the $\delta^{18} \mathrm{O}$ values of shell carbonate that depend on sea surface salinity and temperature were also higher, indicating colder temperatures (salinity is assumed to be more or less constant) (Carré et al., forthcoming). Finally, Schrader and Snorkes (1991), Lyle et al. (1992), Farrell et al. (1995), and Marchant and Hebbeln (1999), notice higher organic carbon contents in marine early mid-Holocene sediment, related to an increased productivity as a result of the enhancement of upwelling strength. However, the doubling of reservoir age at around 7000-8000 cal BP appears much too important to result from an enhancement of upwelling alone because it would imply that upwelled waters had too deep an origin. Two hypothesis could be proposed: 1) the upwelled waters were older, or 2) the origin of waters was different, implying that Antarctic intermediate water $\left(\Delta^{14} \mathrm{C}=-120 \%\right.$, pre-bomb value) were replaced during the upper Holocene by South Antarctic Mode Water $\left(\Delta^{14} \mathrm{C}=-72 \%\right.$, pre-bomb value) that are upwelled today in the Peru-Chile current (Toggweiller et al. 1991). Whatever the cause of the change in reservoir age was, it corresponds to a major change in the circulation of the south Pacific Ocean around 7000-9000 cal BP. Our results agree with Van Beek et al. (2002) that show higher reservoir ages in the Southern Ocean at the beginning of the Holocene and with reconstruction of surface water $\mathrm{pH}$ and $\mathrm{pCO}_{2}$ variations in the western equatorial Pacific Ocean, 
which suggests an important $\mathrm{CO}_{2}$ degassing as a result of the increased intensity of upwellings at that time (Palmer and Pearson 2003).

The enhancement of upwelling that is associated with strong trade winds and lower sea surface temperature suggests that the La Niña phenomenon would have been the prevailing situation during the early Holocene. This implies that El Niño events were less frequent and certainly less strong than during the upper Holocene and the present period, which is in good agreement with what we observe in sedimentological records at Quebrada de los Burros in coastal southern Peru.

\section{ACKNOWLEDGEMENTS}

Thanks are due to Martine Paterne for helpful discussions and Maurice Arnold for AMS measurements. Dr A J T Jull and an anonymous reviewer are acknowledged for suggestions in order to clarify the manuscript. Thanks are due to C Noury for sample preparations. This study was supported by the Franco-Peruvian archaeological project "Pérou-Sud" and the CONCHAS project (PNEDC, CNRS), LSCE contribution nr 1106.

\section{REFERENCES}

Carré M, Bentaleb I, Fontugne M, Lavallée D. Forthcoming. Strong El Niño events during early Holocene: stable isotope evidence from Peruvian sea shell. The Holocene.

Farrell JW, Pedersen TF, Calvert SE, Nielsen B. 1995. Glacial-interglacial changes in nutrient utilization in the equatorial Pacific ocean. Nature 377:514-7.

Fontugne M, Usselmann P, Lavallée D, Julien M, Hatté C. 1999. El Niño variability in the coastal desert of southern Peru during the mid-Holocene. Quaternary Research 52:171-9.

Kennett DJ, Ingram BL, Southon J, Wise K. 2002. Differences in ${ }^{14} \mathrm{C}$ age between stratigraphically associated charcoal and marine shell from archaic period site of kilometer 4, southern Peru: old wood or old water? Radiocarbon 44(1):53-8.

Lavallée D, Julien M, Béarez P, Usselmann P, Fontugne M, Bolaños A. 1999a. Pescadores-recollectores arcaicos del extremo-sur peruano. Excavaciones en la Quebrada de los Burros (Tacna, Perù): primeros resultados 1995-1997. Bulletin Institut Français Etudes Andines 28(1):13-52.

Lavallée D, Bearez P, Chevalier A, Julien M, Usselmann P, Fontugne M. 1999b. Paleoambiente y ocupacion prehistorica del litoral extromo-sur del Peru: las ocupaciones del arcaico en la Quebrada de los Burros y alrededores (Tacna, Peru). In: Kaulicke P, editor. "El periodo arcaico en el Peru: hacia una definition de los origines," Boletin de Arqueologia PUCP 3:393-416.

Lyle MW, Prahl FG, Sparrow MA. 1992: Upwelling and productivity changes inferred from a temperature record in the central equatorial Pacific. Nature 355: 812-5.

Marchant M, Hebbeln D. 1999. High-resolution planktic foraminiferal record of the last 13,300 years from the upwelling area off Chile. Marine Geology 161:11528.
Owen BD. 2002. Marine reservoir age estimates for the far south coast of Peru. Radiocarbon 44(3):701-8.

Palmer MR, Pearson PN. 2003. A 23,000-year record of surface water $\mathrm{pH}$ and $\mathrm{pCO}_{2}$ in the western equatorial Pacific Ocean. Science 300:480-2.

Reimer PJ, McCormac FG. 2002. Marine radiocarbon reservoir corrections for the Mediterranean and Aegean Seas. Radiocarbon 44(1):159-66.

Schader H, Sorknes R. 1991. Peruvian coastal upwelling: late Quaternary productivity changes revealed by diatoms. Marine Geology 97:233-49.

Siani G, Paterne M, Arnold M, Bard E, Metivier B, Tisnérat N, Bassinot F. 2000. Radiocarbon reservoir ages in the Mediterranean Sea and Black Sea. Radiocarbon 42(2):271-80.

Siani G, Paterne M, Michel E, Sulpizio R, Sbrana A, Arnold M, Haddad G. 2001. Mediterranean sea surface radiocarbon age changes since the last glacial maximum. Science 294:1917-20.

Southon J, Kashgarian M, Fontugne M, Metivier B, Yim WWS. 2002. Marine reservoir corrections for the Indian Ocean and Southeast Asia. Radiocarbon 44(1): 167-80.

Stuiver M, Polach H. 1977. Discussion: reporting of ${ }^{14} \mathrm{C}$ data. Radiocarbon 19(3):355-63.

Stuiver M, Reimer PJ, Bard E, Beck WJ, Burr GS, Hughen KA, Kromer B, McCormac G, van der Plicht J, Spurk M. 1998. INTCAL 98 radiocarbon age calibration, 24,000-0 cal BP. Radiocarbon 40(3):104183.

Stuiver M, Braziunas TF. 1993. Modelling atmospheric ${ }^{14} \mathrm{C}$ influences and ${ }^{14} \mathrm{C}$ ages of marine samples to 10,000 BC. Radiocarbon 35(1):137-89.

Tisnerat-Laborde N, Poupeau JJ, Tannau JF, Paterne M. 2001. Development of a semi-automated system for routine preparation of carbonate samples. Radiocarbon 43(2A):299-304. 
Toggweiller JR, Dixon K, Broecker WS. 1991. The Peru upwelling and the ventilation of the South Pacific thermocline. Journal of Geophysical Research 96(C11):20,467-97.

Usselmann P, Fontugne M, Lavallée D, Julien M, Hatté C. 1999. Estabilidad y ruptura dinamicas en el Holoceno de la costa surperuana/el Valle de la Quebrada de los Burros (Departamento de Tacna). Bulletin Institute
Française Etudes Andines 28 (1): 1-11.

Van Beek P, Reyss JL, Paterne M, Gersonde R, Van Der Loeff MR, Kuhn G. 2002. ${ }^{226} \mathrm{Ra}$ in barite: absolute dating of Holocene southern sediments and reconstruction of reservoir ages. Geology 30(8):731-4.

Vita-Finzi C, Roberts N. 1984. Selective leaching of shells for ${ }^{14} \mathrm{C}$ dating. Radiocarbon 26(1):54-8. 